\title{
АНАЛИЗ КОСОВСКОГО И КРЫМСКОГО ПРЕЦЕДЕНТОВ В КОНТЕКСТЕ РЕАЛИЗАЦИИ ПРАВА НАРОДОВ НА САМООПРЕДЕЛЕНИЕ
}

\begin{abstract}
Аннотация. Настоящая статья посвящена исследованию современной практики применения принципа самоопределения и права народов распоряжаться своей судьбой в Косовском и Крымском прецедентах. Объект исследования - Крымский и Косовский прецеденты. Предмет исследования - формы и методы реализации принципа самоопределения в обретении независимости Косово и во вхождении Крыма в состав Российской Федерации. Автор обращает внимание на то, что рассматриваемая в настоящем исследовании политико-правовая проблематика применения права наций на самоопределение, принципа самоопределения и права народов распоряжаться своей судьбой сейчас особенно актуальна в связи с событиями, произошедшими в 2014 году в Украине и повлекшими отделение Крыма с его последующим присоединением к Российской Федерации. Методологическая база исследования включает в себя системный, структурно-функциональный, сравнительный подходы, методы индукции, дедукции, наблюдения, анализа, синтеза, моделирования. Автор приходит к выводу, что, исходя из фактических обстоятельств, право на самоопределение в Крыму население полуострова безусловно имело, а осуществление самоопределения произошло в соответствии с международными стандартами, прецедентами и процедурами. При этом существующую аналогию с отделением Косово также можно считать обоснованной.

Ключевые слова: геополитика, Россия, мировая политика, внешняя политика США, социально-политические процессы, дипломатия, интересы, государство, безопасность, США.

Review: This article is devoted to the study of the current practice of implementation of the principle of self-determination and the right of peoples to self-determination in the precedents of Kosovo and Crimea. The object of the study includes the Crimean and the Kosovo precedents. The subject of the research is the form and the methods of implementation of the principle of self-determination in the independence of Kosovo and in joining of Crimea into the territory of the Russian Federation. The methodological base of the research includes the systems approach, the structural-functional and comparative approaches, the methods of induction, deduction, observation, analysis, synthesis, simulation.The author draws attention to the fact that the considered political and legal problem of application of the right of nations to selfdetermination and the principle of self-determination is now especially important due to the events of 2014 in Ukraine, which led to the separation of Crimea and its subsequent accession into the Russian Federation. The author concludes that, in terms of the actual circumstances, the Crimean population certainly possessed the right to self-determination, and the implementation of this principle followed the international standards, precedents and procedures. The existing analogy with the separation of Kosovo can also be considered reasonable.
\end{abstract}

Keywords: diplomacy, socio-political processes, U.S. foreign policy, world politics, Russia, geopolitics, interests, state, security, USA.

$\Gamma$ руппы, стремящиеся обрести независимость, как правило, позиционируют самоопределение в качестве абсолютного права. С другой стороны, государства, которые противодействуют отделению, рассматривают территориальную целостность как абсолютное право государств. В науке международного права принято считать, что истинным является компромиссный вариант, при котором учитываются как право народов на самоопределение, так и право государства на сохранение территориальной целостности.

Как следует из декларации Генеральной Ассамблеи ООН О принципах международного права, решения по делу Квебек (Quebec case, Верховный суд
Канады) и частично из консультативного заключения Международного Суда ООН по Косово, международное право фактически является нейтральным по вопросу одностороннего отделения. Это означает, что одностороннее отделение является ни запрещенным, ни прямо разрешенным. Кроме того, для целей международного права не имеет значения, является ли отделение прямо запрещенным в соответствии с внутренним законодательством.

Как отметил Верховный суд Канады, новое государственное образование может провозгласить независимость неконституционным способом и, тем не менее, стать независимым, если другие государства готовы признать это (Quebec case, пункт 155). 
Однако на практике провозглашение независимости может быть воплощено за счет иностранной военной помощи. Это тот случай, когда своеобразный нейтралитет международного права заканчивается, ведь международное право является нейтральным только по отношению к односторонним по своему характеру декларациям, но не к ситуациям, при которых имеет место влияние внешних факторов.

В частности, Международный Суд ООН отметил в своем консультативном заключении, что «незаконность, которая приписывается к некоторым другим случаям провозглашения независимости ... вытекает не из одностороннего характера этих деклараций как таковых, а из того, что они были или являются связанными с незаконным применением силы или другими вопиющими нарушениями норм общего международного права, в частности норм императивного характера» [1].

События 2014 г. не просто поставили Крым в центр внимания мирового сообщества, но и заставляют теоретиков и практиков международного права вновь и вновь обращаться к основам принципа равноправия и самоопределения народов. Это связано с процессами отделения Крымского полуострова от Украины, организации референдума 16.03.2014 г., при котором самопровозглашенная власть Крыма апеллировала именно к принципу самоопределения народов. Соответственно, вопросы права населения на самоопределение пока требует всестороннего и объективного анализа.

Более правильным представляется сравнительное исследование этого случая и самоопределения Косово, поскольку и самопровозглашенная крымская власть, и российские чиновники, в том числе министр иностранных дел С.Лавров, неоднократно сравнивали ситуацию в Крыму с ситуацией в Косово, призывая рассматривать обе как в равной степени «особые» [1]. В преамбуле «Декларации о независимости Автономной Республики Крым» приводится ссылка на «подтверждение Международным Судом ООН по Косово от 22 июля 2010 того факта, что одностороннее провозглашение независимости частью государства не нарушает любые нормы международного права».

Следует отметить, что принцип самоопределения народов представляется достаточно спорным и часто противоречит иному основополагающему принципу международного права - принципу целостности государства. Ярким примером неоднозначности данного принципа является Крымский прецедент.

Как известно, Крым являлся особым регионом Украины. В мае 1944 г. около 200 тысяч крымских татар были депортированы со своей родины в среднеазиатские регионы СССР. Официальные причи- ны были зафиксированы в постановлении Государственного Комитета Обороны СССР № ГОКО-5859 от 11 мая 1944 г. [2] о выселении крымских татар, в котором было указано, что депортация проводится потому, что «в период Отечественной войны многие крымские татары изменили Родине, дезертировали из частей Красной Армии, оборонявших Крым, и переходили на сторону противника, вступая в сформированные немцами добровольческие татарские воинские части, боровшиеся против Красной Армии». Затем было выселено более 225 тыс. татар, болгар, греков, армян, представителей других национальностей. Последствиями этих непродуманных идеологических действий стали экономический хаос в регионе, возникновение множества социальных и национальных проблем, которые уже независимая Украина, впрочем, так и не решила. [3]

После окончания Великой Отечественной войны СССР заново переселял в Крым россиян и украинцев, проводя при этом политику русификации последних. 4/5 русскоязычного населения проживает на территории Крыма не более 60-70 лет. Характерно, что в 1921-1945 гг. Крым имел статус автономной ССР, национальный (крымскотатарский) характер автономии подтверждается языковой, культурной, кадровой политикой СССР, а ликвидация крымской автономии прямо увязывалась властью Советского Союза с депортацией из нее крымско-татарского народа; при этом за новообразованным русскоязычным населением Крыма властью СССР прав на автономию, естественно, не признавалось.

19 февраля 1954 г. Президиум Верховного Совета СССР принял решение о передаче Крымской области в состав УССР. Передача имело целью не только обеспечение хозяйственного развития, претерпевавшего упадок в те времена полуострова, но и закрепление последствий депортации крымскотатарского народа. В независимой Украине Крым получил статус автономной республики, не основанное на реализации права на самоопределение. Однако в законодательстве Украины была оставлена возможность развития правового статуса крымско-татарского народа. Так, Конституция Украины 1996 г. [4] закрепила наличие в украинском народе коренных этносов; в ряде последующих нормативных актов крымско-татарский этнос был признан (назывался) народом, что говорит о его косвенном признании как коренного.

Как известно, в феврале-марте 2014 г. Крымский полуостров на фоне смены государственной власти, связанной с ущемлением русскоязычного населения юго-восточных регионов Украины, вышел из состава Украины и подал прошение о присоединении к составу Российской Федерации. 
6 марта 2014 г. Верховная Рада АРК на своем заседании проголосовала за присоединение региона в состав России и обратилась к российскому президенту и парламенту с просьбой начать процедуру предоставления Крыму статуса субъекта РФ. Кроме того, крымский парламент принял решение о проведении 16 марта 2014 г. референдума о статусе Крыма и утвердил вопросы, вынесенные на него:

«- Вы за воссоединение Крыма с Россией на правах субъекта Российской Федерации?

- Вы за восстановление действия Конституции Республики Крым 1992 года и за статус Крыма как части Украины?»

Аналогичное решение о вхождении в состав России на правах отдельного субъекта федерации принял Севастопольский городской совет. Последний также решила принять участие в крымском референдуме 16 марта. К вопросам крымского референдума севастопольцам был добавлен такой:

«- Необходимо ли городу Севастополю войти в состав Российской Федерации как субъекту Российской Федерации?»

11 марта 2014 г. Верховная Рада АРК и городской совет Севастополя на своих сессиях приняли Декларацию независимости Автономной Республики Крым и города Севастополь: за документ проголосовали 78 из 81 депутата крымского парламента. [5]

16 марта 2014 г. экстренно организованный референдум о статусе Крыма состоялся. На нем практически не присутствовали иностранные наблюдатели, ведь мировое сообщество не признало референдум. Участие в волеизъявлении приняли $81,4 \%$ граждан, имевших такое право. За присоединение к России в Крыму проголосовало 96,77\% участников голосования, в Севастополе - 95,6\%. [6] Российский президент и парламент приняли решение о принятии Крымского полуострова в состав РФ. [7]

В марте 2014 г. состоялось более 10 заседаний Совета Безопасности Организации Объединенных Наций, посвященных событиям в Крыму. СБ ООН в результате использования Россией права вето так и не смогла принять никаких решений. 15 марта 2014 г. РФ заблокировала принятие проекта резолюции, осуждающей запланированный на 16 марта референдум в Крыму об отделении от Украины. Из 15 членов Совета Безопасности 13 проголосовали за резолюцию (постоянные члены США, Великобритания и Франция, а также все 10 непостоянных членов - Аргентина, Австралия, Чад, Чили, Иордания, Литва, Люксембург, Нигерия, Южная Корея и Руанда), Китай воздержался, Россия была единственной, кто проголосовал против. Так, резолюция не была принята.
В свою очередь, 27 марта 2014 г. на специальном заседании 68-й сессии Генеральной Ассамблеи $\mathrm{OOH}$ открытым голосованием стран-членов ООН (100 из которых высказались «за», 11 - «против», а 58 - воздержались) была принята Резолюция о поддержке территориальной целостности Украина. Референдум и все дальнейшие действия правительства Крыма и РФ были признаны не имеющими юридической силы. [8]

12 марта лидеры «Большой семерки» (Канады, Франции, Германии, Италии, Японии, Великобритании, Соединенных Штатов Америки), а также президент Европейского совета и президент Европейской комиссии обнародовали заявление, в котором призвали Российскую Федерацию прекратить все усилия по изменению статуса Крыма, что противоречит украинскому законодательству и нарушает нормы международного права. [9]

Что касается признания Крыма в составе РФ, то по итогам проведения референдума его признали легитимным Северная Корея, Беларусь, Монголия, Сирия, Венесуэла, Армения, Казахстан, Киргизия и Афганистан. [10] В дальнейшем иные страны мира признали легитимность присоединения Крыма к РФ, а с текущего года и Евросоюз фактическими действиями (выдача виз крымчанам в качестве граждан РФ) признал присоединение Крыма к РФ легальным. [11]

Российское руководство, обосновывая присоединение Крыма, ссылается на Устав ООН и Декларацию 1970 года о принципах международного права, закрепляющие право на самоопределение, в том числе «свободное присоединение к независимому государству или объединение с ним», которое, по мнению РФ, было реализовано «в экстремальных условиях невозможности реализации [населением Крыма] права на самоопределение в рамках Украины, усугубившихся приходом к власти незаконных властей, которые не представляют весь украинский народ», а также на прецедент с признанием одностороннего провозглашения независимости Косова. Кроме того, Россия заявляет, что не превышала предельную численность войск в Крыму, установленную в соглашениях по Черноморскому флоту, и «не нарушала» их. [12]

Таким образом, международные институты, а также отдельные государства заняли различные позиции: часть из них не признали референдум в Крыму как нарушающий законодательство Украины и международное право, осудили действия РФ по аннексии Крыма; иные считают выход Крыма из состава Украины и присоединение к России легитимным.

При этом и Россия, и отдельные международные институции и государства проводят параллели между провозглашением независимости Косово 
и самоопределением в Крыму, в связи с чем считаем целесообразным обратиться к истории Республики Косово.

Республика Косово в настоящее время является частично признанным государством, расположенным на Балканском полуострове, в географическом регионе Косово. Согласно Конституции Сербии, территория Республики Косово является частью Республики Сербия и входит в ее состав как Автономный край Косово и Метохия, однако фактически Косово властями Сербии не контролируется. Часть Косова, населённая преимущественно сербами, не подчиняется властям в Приштине столице Косово. [13]

Важно отметить, что 14-15 февраля 2012 сербы, которые образуют своеобразный анклав в Косово, решили еще раз подтвердить свое неподчинение центральной власти, проведя консультативный референдум. Перед избирателями был поставлен вопрос: «Признаете ли вы институты так называемой Республики Косово?», на который большинство опрошенных дали отрицательный ответ. Показательно, что кроме предполагаемого непризнания законности данного референдума со стороны Косово и западных государств, имело место и его осуждения со стороны Сербии, которая считала его необоснованным и деструктивным. [14] Данный факт позволяет предположить, что сербы на территории Косово не подвергаются преследованиям и гонениям, что гарантируется и присутствием иностранных миротворческих групп [15], также, как и отсутствуют в настоящий момент озвученные Украиной якобы имеющиеся в наличии гонения крымских татар и украинцев на территории Крыма в составе РФ.

Что касается Косово, то и в XX веке ситуация на указанной территории была достаточно острой, а начало 1990-х гг. и вовсе обернулось кровопролитной войной на Балканах. В 1995 г. было заключено Дейтонское соглашение, означавшее окончание войны в Боснии. Однако, вопреки надеждам косовских албанцев, международное сообщество практически не уделяло внимания ситуации в Косово, и до 1996 г. Освободительная армия Косово (далее - ОАК), партизанское группировки этнических албанцев, преимущественно занималось ненасильственным движением сопротивления, начав осуществлять вооруженное сопротивление сербским силам безопасности, в результате чего в Косово началась война. [16]

К 1998 г., с ростом уровня насилия, выросла и заинтересованность Запада в делах в Косово. Сербские власти были вынуждены подписать соглашение о прекращении огня и частичном отступлении, реализация которого контролировалась ОБСЕ. Однако соглашение о прекращении огня не было соблюдено, и боевые действия возобновились в декабре 1998 г., в январе 1999 г. состоялась резня в Рачаке. [17] В течение нескольких недель была созвана многосторонняя международная конференция; до начала марта был подготовлен проект соглашения (Соглашение Рамбуйе), которое призывало к восстановлению автономии в Косово и размещению на его территории миротворческих сил НАТО. Сербская сторона отказалась подписать соглашение.

В период с 24 марта и 10 июня 1999 г. НАТО осуществляло бомбардировки Югославии, что должно было заставить Президента Сербии С.Милошевича вывести войска из Косово. [18] Бои между албанскими вооруженными группировками и югославскими силами продолжались и привели к массовому переселению населения из Косово. Во время конфликта примерно миллион этнических албанцев бежали или были насильно изгнаны из Косово. В первой половине 1999 г. было зафиксировано более 11 тыс. смертей, 3000 человек числятся пропавшими без вести. [19] В конечном счете, в июне 1999 г. С. Милошевич согласился на иностранное военное присутствие в Косово и вывод своих войск.

С мая 1999 г. Международный уголовный трибунал для бывшей Югославии начал осуществлять судебное преследование за преступления, совершенные во время войны в Косово. Были осуждены девять сербских военных командиров, которым были предъявлены обвинения за преступления против человечества и нарушение законов и обычаев войны в Косово в 1999 г. Они направляли, поощряли или поддерживали кампанию террора и насилия против косовских албанцев (гражданских лиц) и действовали с целью изгнания значительной части из них из Косово (в результате, около 800 тыс. албанцев покинули Косово). [20]

10 июня 1999 г. Совет Безопасности ООН принял резолюцию №1244, которая предусматривала помещение Косово под временную администрацию ООН (МООНК, осуществляла законодательные, исполнительные и судебные функции) и уполномочила на деятельность военные силы Косово под руководством миротворческих сил НАТО. Резолюция №1244 предусмотрела, что Косово будет иметь автономию в рамках Союзной Республики Югославии и подтвердила территориальную целостность Югославии, продолжателем которой стала Республика Сербия. [21]

В 2006 г. начались международные переговоры, направленные на определение окончательного статуса Косово, как это предусмотрено в резолюции СБ ООН. Несмотря на прогресс по техническим вопросам, стороны остались с диаметрально противоположными взглядами по вопросу о статусе Косово. 
Дальнейшее одностороннее провозглашение независимости Косово 17 февраля 2008 г. вызвало неоднозначную реакцию в международном сообществе. Сейчас независимость Косово от Сербии признали 108 государств из 193 (56\% членов Организации Объединенных Наций), в том числе США, Канада, Япония, Австралия, Великобритания, Франция, Германия.

Следует подчеркнуть, что создание государства Косово может быть объяснено только постконфликтным юридическим урегулированием, установленным резолюцией №1244, и осуществлением права на самоопределение народов. Соответственно, можно сделать вывод, что любые аргументы относительно законности или незаконности предыдущего вмешательства НАТО не влияют на вопрос о законности создания соответствующего государства.

По мнению правительств США и некоторых государств ЕС [22], ситуация в Косово является уникальной и признание его независимости не должно быть прецедентным для других самопровозглашенных образований. Так, А.Меркель на Парламентской Ассамблее Совета Европы отметила: «Мы считаем, что на основе Косово не может быть никаких параллелей относительно других регионов» [23]. В качестве обоснования уникальности Косово госсекретарь США К. Райс назвала комбинацию следующих факторов: общий контекст распада Югославии, этнические чистки и преступления в отношении гражданского населения Косово и длительный период пребывания края под управлением администрации $0 \mathrm{OH}$.

С учетом указанного, Косовский прецедент признан уникальным и до 2014 года его повторений не наблюдалось. В то же время, как указывалось ранее, Крымский прецедент вызывает споры о наличии параллелей с Косовским прецедентом. Далее проведем анализ, направленный на выявление общего и различного в Косовском и Крымском прецедентах.

Итак, что же общего и отличного между двумя ситуациями - в Крыму и Косово? И в Косово, и в Крыму состоялись попытки самоопределения, инициированные движением косоваров (албанцев) в Косово и пророссийским движением на Крымском полуострове.

Теория самоопределения в международном праве допускает три случая, при которых признается право на провозглашение независимости:

a) мировым признается право на самоопределение колоний, то есть, стран, колонизированных иностранными силами;

b) такое право признают за оккупированными территориями;

c) на определенной части какой-либо страны происходят систематические нарушения прав человека, издевательства над гражданским на- селением, отказ в праве голосовать, иметь своих представителей в центральном правительстве. В таком случае можно говорить о праве на самоопределение и самоуправление или прекращении нарушения прав человека. Последний случай имел место в Косово: невозможность самоопределения албанцев в рамках Сербии создала предпосылки для выхода из ее состава и создание собственного государства. Аналогичная ситуация сложилась и в Крыму, когда в Украине начались ограничения населения по принципу использования ими русского языка. И, несмотря на отсутствие непосредственного насилия по отношении к жителям Крымского полуострова, ограничения в осуществлении ими политических прав имели место быть. Так, министр иностранных дел РФ С. Лавров 14 марта 2014 г. заявил: «То, что в Крыму всеми отмечается отсутствие каких-либо серьезных правонарушений, обуславливается именно тем, что были приняты дополнительные меры, народные дружины самообороны были полны решимости не допустить повторения того, что случилось на Майдане в Киеве, где, кстати, продолжает оставаться палаточный лагерь» [24].

Кроме того, международное сообщество на протяжении многих лет пыталось решить проблемы, связанные с угнетением албанцев на территории Косово. Была введена администрация ООН, проведены многочисленные раунды переговоров. Провозглашение независимости состоялось через много лет после начала этих усилий. И, несмотря на то, что срок от начала нарушение прав русских в Крыму до самоопределения Крыма занял несколько недель, Косовский прецедент был использован по аналогии с учетом того, что нарушения прав русских в Крыму уже наблюдались, а обеспечение права на самоопределение народа позволило избежать кровопролития.

Аналогию можно провести и относительно процедуры отделения Косово в порядке международных судебных процедур. Так в меморандуме США, представленном в Международный Суд ООН по делу о соответствии международному праву односторонней декларации о независимости Косово, отмечается, что «декларации независимости могут и по своей сути часто нарушают внутреннее право, ... однако это не означает, что имело место нарушение международного права» .

Сам Международный Суд «согласился с этим подходом и при анализе соответствия международному праву декларации о независимости Косово даже не стал исследовать вопрос о действительности этой декларации в свете Конституции Сербии или Конституции СФРЮ. В этой связи интересен следующий вывод Суда: «Суд просили вынести заключение не в отношении того, соответствует ли 
декларация независимости какой-либо норме внутреннего права, а в отношении того, соответствует ли она нормам международного права. Суд может ответить на этот вопрос посредством анализа международного права, и ему нет нужды вторгаться при этом в систему внутреннего права»» [25].

Таким образом, вопрос о том соответствует ли процесс отделения Крыма от Украины и его вхождения в состав России Конституции Украины или нет, не влияет на признание его правомерным с точки зрения международного права. Следователь- но, чтобы провозглашение независимости Крыма и связанный с этим процесс в форме референдума считался недействительным или неправомерным следует определить наличие специфического запрета на такие действия в международном праве. Как это изложено выше, Международный Суд в своем консультативном заключении «О соответствии международному праву односторонней декларации о независимости Косово» пришел к выводу, что «общее международное право не содержит запрет, применимый к декларациям независимости» [25].

\section{Библиография:}

1. Jure Vidmar. Crimea's Referendum and Secession: Why it Resembles Northern Cyprus More than Козоvо [Электронный ресурс]. // Режим доступа: http://www.ejiltalk.org/crimeas-referendum-and-secession-why-it-resembles-northerncyprus-more-than-kosovo

2. Лавров: Крым еще более особый случай, чем Косово [Электронный ресурс]. // Режим доступа: http://www.vz.ru/ news/2014/3/14/677145.html

3. Постановление ГКО СССР № ГОКО-5859 от 11 мая 1944 г. за подписью И. В. Сталина [Электронный ресурс]. // Режим доступа: http://www.memorial.krsk.ru/DOKUMENT/USSR/440511.htm

4. Депортация крымских татар: исторические и правовые оценки [Электронный ресурс]. // Режим доступа: http:// www.xenodocuments.org.ua/factitem/1014

5. Конституция Украины (Ведомости Верховной Рады Украины (ВВР Украины), 1996, № 30, ст. 141) [Электронный pecypc]. // Режим доступа: http://rada.gov.ua/uploads/documents/27396.pdf

6. Парламент Крыма принял Декларацию о независимости [Электронный ресурс]. // Режим доступа: http://www. bbc.co.uk/ukrainian/politics/2014/03/140311_crimea_rada_decisions_sx.shtml

7. Явка в Севастополе на референдуме составила 89,5\%, в Автономной Республике Крым-81,36\% [Электронный peсурс]. // Режим доступа: http://www.c-inform.info/news/id/766

8. UNSC Discusses Human Rights Violations And Freedom Of Press In Crimea [Электронный ресурс]. // Режим доступа: http://en.cihan.com.tr/news/UNSC-discusses-human-rights-violations-and-freedom-of-press-in-Crimea_0312-CHMTM 5MDMxMi80;jsessionid=B5ypJUb1sKOYIQ082tqzVtQX

9. General Assembly Adopts Resolution Calling Upon States Not To Recognize Changes In Status Of Crimea Region [Электронный ресурс]. // Режим доступа: http://www.un.org/News/Press/docs/2014/ga11493.doc.htm

10. G7 warns Russia on 'annexing' Crimea [Электронный ресурс]. // Режим доступа: http://www.bbc.com/news/worldeurope-26547138

11. Карта мира: кто признал и кто осудил присоединение Крыма к России (по состоянию на 25 марта 2014 г.) [Электронный ресурс]. // Режим доступа: http://www.profi-forex.org/novosti-mira/novosti-sng/ukraine/ entry1008205050.html

12. Евросоюз признал Крым частью России [Электронный ресурс]. // Режим доступа: http://dni.ru/ polit/2014/11/13/286219.html

13. Правовые обоснования позиции России по Крыму и Украине [Электронный ресурс]. // Режим доступа: http:// www.russianunesco.ru/rus/article/1636

14. Kosovo seeks firm borders with Montenegro, Serbia [Электронный ресурс]. // Режим доступа: http://www.setimes. com/cocoon/setimes/xhtml/en_GB/features/setimes/features/2012/08/23/feature-01

15. Northern Serbs Vote 'No' to Kosovo [Электронный ресурс]. // Режим доступа: http://www.balkaninsight.com/en/ article/99-74-kosovo-serbs-say-no-to-pristina

16. Sterio, Milena. The Case of Kosovo: Self-Determination, Secession, and Statehood Under International Law [Электронный ресурс]. // Режим доступа: http://www.jstor.org/stable/10.5305/procannmeetasil

17. Rogel C. Kosovo: Where It All Began. // International Journal of Politics, Culture, and Society, Vol. 17. - No. 1. - 2003. pp. 167-182.

18. Shinasi A. The Serb-Albanian War, and the International Community's Miscalculations. // The International Journal of Albanian Studies. - №1. - 1998. - pp. 15-19.

19. Operation Allied Force (23 March-10 June 1999) [Электронный ресурс]. // Режим доступа: http://www.nato.int/ kosovo/all-frce.htm

20. 3000 missing in Kosovo [Электронный ресурс]. // Режим доступа: http://news.bbc.co.uk/2/hi/europe/781310.stm

21. ICTY judgements [Электронный ресурс]. // Режим доступа: http://www.icty.org/sid/10095

22. Resolution 1244 (1999) Adopted by the Security Council at its 4011th meeting, on 10 June 1999 // UN Security Council. 1999. - 8 p.

23. Kosovo, Ue: «Decidono gli Stati» D’Alema: «L'Italia lo riconoscerà» [Электронный ресурс]. // Режим доступа: http:// www.repubblica.it/2008/02/sezioni/esteri/kosovo-indipendenza/kosovo-diplomazia/kosovo-diplomazia.html

24. Angela Merkel: Kosovo, a sui generis case [Электронный ресурс]. // Режим доступа: http://newkosovareport. com/20080416883/Politics/angela-merkel-kosovo-a-sui-generis-case.html

25. Лавров: Крым еще более особый случай, чем Косово [Электронный ресурс]. // Режим доступа: http://www.vz.ru/ news/2014/3/14/677145.html 
26. Консультативное заключение «О соответствии международному праву односторонней декларации о независимости Косово». // Доклады Международного Суда 2010, стр. 12, пар 26.

27. Манойло А.В. Парадигмы управления международными конфликтами: конкуренция или конфронтация. // Национальная безопасность / nota bene. 2011. № 5. С. 135-142.

28. Манойло А.В. Мирное разрешение международных конфликтов: национальные концепции, модели, технологии. // Власть. 2008. № 8. С. 79-83.

29. Манойло А.В. Актуальные вопросы модернизации современной культурно-цивилизационной теории управления международными конфликтами. // Национальная безопасность / nota bene. - 2011. - № 4. - C. 60-66.

30. Следзевский И.В., Филиппов В.Р., Хабенская Е.О. Влияние СМИ на формирование этнических стереотипов общественного сознания в столичном мегаполисе. М., 2005.

31. Филиппова Е.И., Филиппов В.Р. Государство и общество перед лицом социального кризиса (две парадигмы: российская и французская) // Ежегодный доклад Сети этнологического мониторинга и раннего предупреждения конфликтов. 2005. Москва, 2006. С. 12-25.

32. Калачев Д.Н. Основные направления сотрудничества России и НАТО // Тренды и управление. - 2015. - 1. - С. 36 43. DOI: 10.7256/2307-9118.2015.1.13712.

33. Гушер А.И. Вызовы и угрозы безопасности России // Мировая политика. - 2014. - 1. - C. 64 - 75. DOI: 10.7256/24098671.2014.1.10748. URL: http://www.e-notabene.ru/wi/article_10748.html

34. Семченков А.С. Военные угрозы безопасности государств в условиях глобализации // Конфликтология / nota bene. - 2015. - 3. - C. 292 - 304. DOI: 10.7256/2409-8965.2015.3.14334.

35. Глущенко В.В. Геоэкономический фактор обеспечения национальной безопасности государства // Национальная безопасность / nota bene. - 2015. - 5. - C. 672 - 682. DOI: 10.7256/2073-8560.2015.5.16427.

36. Фельдман П.Я. Политическое участие групп интересов в условиях глобальной дестабилизации // Тренды и управление. - 2015. - 2. - С. 134 - 137. DOI: 10.7256/2307-9118.2015.2.14236.

37. Будаев А.В. Основные подходы к использованию «мягкой силы» в интересах реализации внешней политики Российской Федерации // Тренды и управление. - 2014. - 2. - С. 175 - 187. DOI: 10.7256/2307-9118.2014.2.11784.

38. Карпович О.Г. Международные организации и их роль в предупреждении, урегулировании и разрешении этнополитических конфликтов // Национальная безопасность / nota bene. - 2014. - 3. - С. 398 - 405. DOI: 10.7256/20738560.2014.3.11786.

39. Бородинов Е.Н. Причины и следствия государственного переворота на Украине // Мировая политика. - 2014. 3. - C. 36 - 59. DOI: 10.7256/2409-8671.2014.3.11501. URL: http://www.e-notabene.ru/wi/article_11501.html

40. Буневич Д.С. Крымский кризис 2014 года и создание новой архитектуры международных отношений // Конфликтология / nota bene. - 2015. - 2. - C. 133 - 139. DOI: 10.7256/2409-8965.2015.2.14333.

41. Бочарников И.В. Неядерное сдерживание как фактор обеспечения безопасности и суверенитета России в современных условиях // Тренды и управление. - 2015. - 2. - С. 120 - 128. DOI: 10.7256/2307-9118.2015.2.14226.

42. Виноградова Е.А. Информационные войны в Латинской Америке // Тренды и управление. - 2014. - 4. - С. 372 384. DOI: $10.7256 / 2307-9118.2014 .4 .13080$.

\section{References (transliterated):}

1. Jure Vidmar. Crimea's Referendum and Secession: Why it Resembles Northern Cyprus More than Kosovo [Elektronnyi resurs]. // Rezhim dostupa: http://www.ejiltalk.org/crimeas-referendum-and-secession-why-it-resembles-northerncyprus-more-than-kosovo

2. Lavrov: Krym eshche bolee osobyi sluchai, chem Kosovo [Elektronnyi resurs]. // Rezhim dostupa: http://www.vz.ru/ news/2014/3/14/677145.html

3. Postanovlenie GKO SSSR № GOKO-5859 ot 11 maya 1944 g. za podpis’yu I. V. Stalina [Elektronnyi resurs]. // Rezhim dostupa: http://www.memorial.krsk.ru/DOKUMENT/USSR/440511.htm

4. Deportatsiya krymskikh tatar: istoricheskie i pravovye otsenki [Elektronnyi resurs]. // Rezhim dostupa: http://www. xenodocuments.org.ua/factitem/1014

5. Konstitutsiya Ukrainy (Vedomosti Verkhovnoi Rady Ukrainy (VVR Ukrainy), 1996, № 30, st. 141) [Elektronnyi resurs]. // Rezhim dostupa: http://rada.gov.ua/uploads/documents/27396.pdf

6. Parlament Kryma prinyal Deklaratsiyu o nezavisimosti [Elektronnyi resurs]. // Rezhim dostupa: http://www.bbc.co.uk/ ukrainian/politics/2014/03/140311_crimea_rada_decisions_sx.shtml

7. Yavka v Sevastopole na referendume sostavila 89,5\%, v Avtonomnoi Respublike Krym-81,36\% [Elektronnyi resurs]. // Rezhim dostupa: http://www.c-inform.info/news/id/766

8. UNSC Discusses Human Rights Violations And Freedom Of Press In Crimea [Elektronnyi resurs]. // Rezhim dostupa: http://en.cihan.com.tr/news/UNSC-discusses-human-rights-violations-and-freedom-of-press-in-Crimea_0312-CHMTM 5MDMxMi80;jsessionid=B5ypJUb1sKOYIQ082tqzVtQX

9. General Assembly Adopts Resolution Calling Upon States Not To Recognize Changes In Status Of Crimea Region [Elektronnyi resurs]. // Rezhim dostupa: http://www.un.org/News/Press/docs/2014/ga11493.doc.htm

10. G7 warns Russia on 'annexing' Crimea [Elektronnyi resurs]. // Rezhim dostupa: http://www.bbc.com/news/worldeurope-26547138

11. Karta mira: kto priznal i kto osudil prisoedinenie Kryma k Rossii (po sostoyaniyu na 25 marta 2014 g.) [Elektronnyi resurs]. // Rezhim dostupa: http://www.profi-forex.org/novosti-mira/novosti-sng/ukraine/entry1008205050.html

12. Evrosoyuz priznal Krym chast'yu Rossii [Elektronnyi resurs].// Rezhim dostupa: http://dni.ru/polit/2014/11/13/286219.html

13. Pravovye obosnovaniya pozitsii Rossii po Krymu i Ukraine [Elektronnyi resurs]. // Rezhim dostupa: http://www. russianunesco.ru/rus/article/1636

14. Kosovo seeks firm borders with Montenegro, Serbia [Elektronnyi resurs]. // Rezhim dostupa: http://www.setimes.com/ cocoon/setimes/xhtml/en_GB/features/setimes/features/2012/08/23/feature-01 
15. Northern Serbs Vote 'No' to Kosovo [Elektronnyi resurs]. // Rezhim dostupa: http://www.balkaninsight.com/en/ article/99-74-kosovo-serbs-say-no-to-pristina

16. Sterio, Milena. The Case of Kosovo: Self-Determination, Secession, and Statehood Under International Law [Elektronnyi resurs]. // Rezhim dostupa: http://www.jstor.org/stable/10.5305/procannmeetasil

17. Rogel C. Kosovo: Where It All Began. // International Journal of Politics, Culture, and Society, Vol. 17. - No. 1. - 2003. - rr. 167-182.

18. Shinasi A. The Serb-Albanian War, and the International Community's Miscalculations. // The International Journal of Albanian Studies. - №1. - 1998. - pp. 15-19.

19. Operation Allied Force (23 March-10 June 1999) [Elektronnyi resurs]. // Rezhim dostupa: http://www.nato.int/kosovo/ all-frce.htm

20. 3000 missing in Kosovo [Elektronnyi resurs]. // Rezhim dostupa: http://news.bbc.co.uk/2/hi/europe/781310.stm

21. ICTY judgements [Elektronnyi resurs]. // Rezhim dostupa: http://www.icty.org/sid/10095

22. Resolution 1244 (1999) Adopted by the Security Council at its 4011th meeting, on 10 June 1999 // UN Security Council. 1999. - $8 \mathrm{p}$.

23. Kosovo, Ue: «Decidono gli Stati» D’Alema: «L'Italia lo riconoscerà» [Elektronnyi resurs]. // Rezhim dostupa: http://www. repubblica.it/2008/02/sezioni/esteri/kosovo-indipendenza/kosovo-diplomazia/kosovo-diplomazia.html

24. Angela Merkel: Kosovo, a sui generis case [Elektronnyi resurs]. // Rezhim dostupa: http://newkosovareport. com/20080416883/Politics/angela-merkel-kosovo-a-sui-generis-case.html

25. Lavrov: Krym eshche bolee osobyi sluchai, chem Kosovo [Elektronnyi resurs]. // Rezhim dostupa: http://www.vz.ru/ news/2014/3/14/677145.html

26. Konsul'tativnoe zaklyuchenie «0 sootvetstvii mezhdunarodnomu pravu odnostoronnei deklaratsii o nezavisimosti Kosovo». // Doklady Mezhdunarodnogo Suda 2010, str. 12, par 26.

27. Manoilo A.V. Paradigmy upravleniya mezhdunarodnymi konfliktami: konkurentsiya ili konfrontatsiya. // Natsional'naya bezopasnost' / nota bene. 2011. № 5. S. 135-142.

28. Manoilo A.V. Mirnoe razreshenie mezhdunarodnykh konfliktov: natsional'nye kontseptsii, modeli, tekhnologii. // Vlast'. 2008. № 8. S. 79-83.

29. Manoilo A.V. Aktual'nye voprosy modernizatsii sovremennoi kul'turno-tsivilizatsionnoi teorii upravleniya mezhdunarodnymi konfliktami. // Natsional'naya bezopasnost' / nota bene. - 2011. - № 4. - C. 60-66.

30. Sledzevskii I.V., Filippov V.R., Khabenskaya E.O. Vliyanie SMI na formirovanie etnicheskikh stereotipov obshchestvennogo soznaniya v stolichnom megapolise. M., 2005.

31. Filippova E.I., Filippov V.R. Gosudarstvo i obshchestvo pered litsom sotsial'nogo krizisa (dve paradigmy: rossiiskaya i frantsuzskaya) // Ezhegodnyi doklad Seti etnologicheskogo monitoringa i rannego preduprezhdeniya konfliktov. 2005. Moskva, 2006. S. 12-25.

32. Kalachev D.N. Osnovnye napravleniya sotrudnichestva Rossii i NATO // Trendy i upravlenie. - 2015. - 1. - C. 36 - 43. DOI: 10.7256/2307-9118.2015.1.13712.

33. Gusher A.I. Vyzovy i ugrozy bezopasnosti Rossii // Mirovaya politika. - 2014. - 1. - C. 64 - 75. DOI: 10.7256/24098671.2014.1.10748. URL: http://www.e-notabene.ru/wi/article_10748.html

34. Semchenkov A.S. Voennye ugrozy bezopasnosti gosudarstv v usloviyakh globalizatsii // Konfliktologiya / nota bene. 2015. - 3. - C. 292 - 304. DOI: 10.7256/2409-8965.2015.3.14334.

35. Glushchenko V.V. Geoekonomicheskii faktor obespecheniya natsional'noi bezopasnosti gosudarstva // Natsional'naya bezopasnost' / nota bene. - 2015. - 5. - C. 672 - 682. DOI: 10.7256/2073-8560.2015.5.16427.

36. Fel'dman P.Ya. Politicheskoe uchastie grupp interesov v usloviyakh global'noi destabilizatsii // Trendy i upravlenie. 2015. - 2. - C. 134 - 137. DOI: 10.7256/2307-9118.2015.2.14236.

37. Budaev A.V. Osnovnye podkhody k ispol'zovaniyu «myagkoi sily» v interesakh realizatsii vneshnei politiki Rossiiskoi Federatsii // Trendy i upravlenie. - 2014. - 2. - C. 175 - 187. DOI: 10.7256/2307-9118.2014.2.11784.

38. Karpovich O.G. Mezhdunarodnye organizatsii i ikh rol' v preduprezhdenii, uregulirovanii i razreshenii etnopoliticheskikh konfliktov // Natsional'naya bezopasnost' / nota bene. - 2014. - 3. - C. 398 - 405. DOI: 10.7256/2073-8560.2014.3.11786.

39. Borodinov E.N. Prichiny i sledstviya gosudarstvennogo perevorota na Ukraine // Mirovaya politika. - 2014. - 3. - C. 36 59. DOI: 10.7256/2409-8671.2014.3.11501. URL: http://www.e-notabene.ru/wi/article_11501.html

40. Bunevich D.S. Krymskii krizis 2014 goda i sozdanie novoi arkhitektury mezhdunarodnykh otnoshenii // Konfliktologiya / nota bene. - 2015. - 2. - C. 133 - 139. DOI: 10.7256/2409-8965.2015.2.14333.

41. Bocharnikov I.V. Neyadernoe sderzhivanie kak faktor obespecheniya bezopasnosti i suvereniteta Rossii v sovremennykh usloviyakh // Trendy i upravlenie. - 2015. - 2. - C. 120 - 128. DOI: 10.7256/2307-9118.2015.2.14226.

42. Vinogradova E.A. Informatsionnye voiny v Latinskoi Amerike // Trendy i upravlenie. - 2014. - 4. - C. 372 - 384. DOI: $10.7256 / 2307-9118.2014 .4 .13080$. 